\title{
THE ROLE OF ENTREPRENEURSHIP IN ECONOMIC GROWTH
}

\author{
Ehsaanullah Moqimzai \\ Master Of Business Administration
}

\begin{abstract}
This study confirms that the level of entrepreneurship in a given country has a significant positive effect on the level of economic growth in that country. Contrary to some established theories, this study has found evidence that the level of entrepreneurship in a given country is not explained by the levels of the traditional causes of economic growth in that country (specifically the amounts of labour, capital, and knowledge that a country possesses as well as the presence or absence of market friendly government policies). Instead, entrepreneurship acts as an independent factor.
\end{abstract}

Keywords- entrepreneurship, economic growth

\section{INTRODUCTION}

One of the most important goals of contemporary economics is determining the factors that cause economic growth. Traditional neoclassical theory holds that the economic growth of a country is determined by the supplies of both labour and capital the country possesses and the level of technology present in that country (Todaro and Smith, p.129). Some neoclassical economists have suggested that both knowledge and pro-market government policies also have a significant influence on economic growth (Audre's and Keelback, p. 605; Todaro and Smith, p. 130). The level of technology in a given society is heavily dependent on the level of knowledge in that society; this paper will regard these two factors as essentially the same. The established neoclassical factors of economic growth are thus the levels of capital and labour present in a given society, the level of knowledge (or technology) present in that society, and the extent to which the government of that society pursues promarket government policies. However, this model ignores any direct effect that entrepreneurship may have on economic growth. This paper will provide evidence that entrepreneurship should be included as an important cause of economic growth independent of the other factors. We will begin with a review of relevant literature, and then move to an overview of the data and variables used along with a description of the statistical methodology. We present the analysis of the relevant empirical results and end with a conclusion detailing possible directions for future research. It is important to note that, for the purposes of this paper, entrepreneurship will be defined as simply the number of new businesses formed in a given time period. Innovation will be defined as the creation of previously unknown economically profitable ideas.

\section{CONCEPT OF ENTREPRENEURSHIP}

Entrepreneurship is the ability and readiness to develop, organize and run a business enterprise, along with any of its uncertainties in order to make a profit. The most prominent example of entrepreneurship is the starting of new businesses.

In economics, entrepreneurship connected with land, labour, natural resources and capital can generate a profit. The entrepreneurial vision is defined by discovery and risk-taking and is an indispensable part of a nation's capacity to succeed in an ever-changing and more competitive global marketplace.

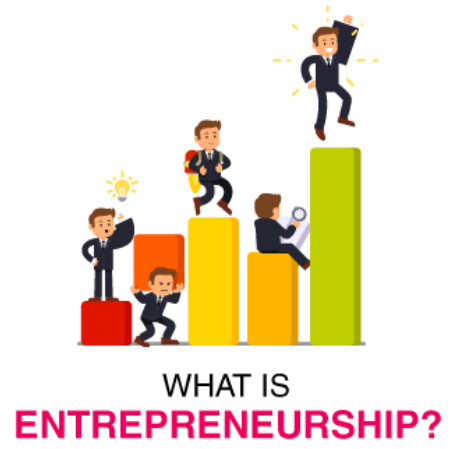

\section{MEANING OF ENTREPRENEUR}

The entrepreneur is defined as someone who has the ability and desire to establish, administer and succeed in a start-up venture along with risk entitled to it, to make profits. The best example of entrepreneurship is the starting of a new business venture. The entrepreneurs are often known as a source of new ideas or innovators, and bring new ideas in the market by replacing old with a new invention. It can be classified into small or home business to multinational companies. In economics, the profits that an entrepreneur makes is with a combination of land, natural resources, labour and capital. 


\section{International Journal of Engineering Applied Sciences and Technology, 2020 \\ Vol. 5, Issue 6, ISSN No. 2455-2143, Pages 116-121 \\ Published Online October 2020 in IJEAST (http://www.ijeast.com)}

In a nutshell, anyone who has the will and determination to start a new company and deals with all the risks that go with it can become an Entrepreneur.

\section{WHAT ARE THE 4 TYPES OF ENTREPRENEURSHIP?}

It is classified into the following types:

\section{Small Business Entrepreneurship-}

These businesses are a hairdresser, grocery store, travel agent, consultant, carpenter, plumber, electrician, etc. These people run or own their own business and hire family members or local employee. For them, the profit would be able to feed their family and not making 100 million business or taking over an industry. They fund their business by taking small business loans or loans from friends and family.

\section{Scalable Startup Entrepreneurship-}

This start-up entrepreneur starts a business knowing that their vision can change the world. They attract investors who think and encourage people who think out of the box. The research focuses on a scalable business and experimental models, so, they hire the best and the brightest employees. They require more venture capital to fuel and back their project or business.

\section{Large Company Entrepreneurship-}

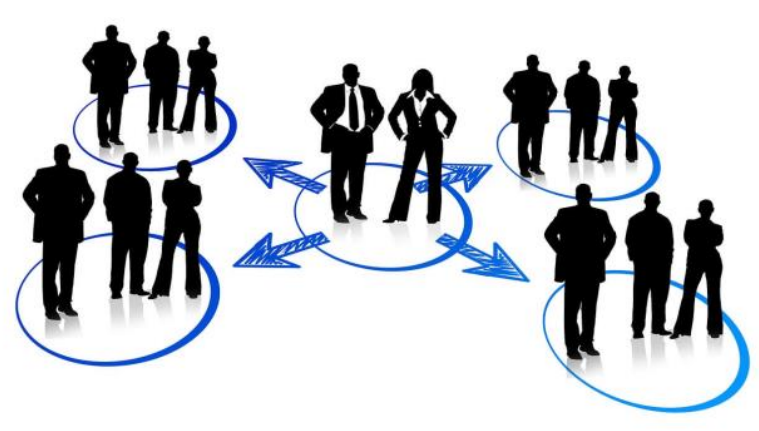

2. Create Jobs: Entrepreneurs are by nature and definition job creators, as opposed to job seekers. The simple translation is that when you become an entrepreneur, there is one less job seeker in the economy, and then you provide employment for multiple other job seekers. This kind of job creation by new and existing businesses is again is one of the basic goals of economic development. This is why the Govt. of India has launched initiatives such as Starts penda to promote and support new startups, and also others like the Make in India initiative to attract foreign companies and their FDI into the Indian economy. All this in turn creates
These huge companies have defined life-cycle. Most of these companies grow and sustain by offering new and innovative products that revolve around their main products. The change in technology, customer preferences, new competition, etc., build pressure for large companies to create an innovative product and sell it to the new set of customers in the new market. To cope with the rapid technological changes, the existing organisations either buy innovation enterprises or attempt to construct the product internally.

\section{Social Entrepreneurship-}

This type of entrepreneurship focuses on producing product and services that resolve social needs and problems. Their only motto and goal is to work for society and not make any profits

\section{7 roles of an Entrepreneurship in economic} growth

1. Wealth Creation and Sharing: By establishing the business entity, entrepreneurs invest their own resources and attract capital (in the form of debt, equity, etc.) from investors, lenders and the public. This mobilizes public wealth and allows people to benefit from the success of entrepreneurs and growing businesses. This kind of pooled capital that results in wealth creation and distribution is one of the basic imperatives and goals of economic development.

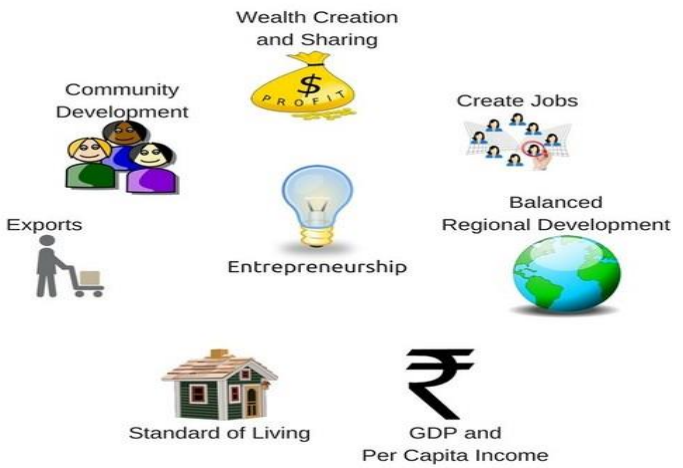

a lot of job opportunities, and is helping in augmenting our standards to a global level.

3.

Balanced

Regional

Development: Entrepreneurs setting up new businesses and industrial units help with regional development by locating in less developed and backward areas. The growth of industries and business in these areas leads to infrastructure improvements like better roads and rail links, airports, stable electricity and water supply, schools, hospitals, shopping malls and other public and 


\section{International Journal of Engineering Applied Sciences and Technology, 2020 \\ Vol. 5, Issue 6, ISSN No. 2455-2143, Pages 116-121 \\ Published Online October 2020 in IJEAST (http://www.ijeast.com)}

private services that would not otherwise be available.

Every new business that locates in a less developed area will create both direct and indirect jobs, helping lift regional economies in many different ways. The combined spending by all the new employees of the new businesses and the supporting jobs in other businesses adds to the local and regional economic output. Both central and state governments promote this kind of regional development by providing registered MSME businesses various benefits and concessions.

4. GDP and Per Capita Income: India's MSME sector, comprised of 36 million units that provide employment for more than 80 million people, now accounts for over $37 \%$ of the country's GDP. Each new addition to these 36 million units makes use of even more resources like land, labor and capital to develop products and services that add to the national income, national product and per capita income of the country. This growth in GDP and per capita income is again one of the essential goals of economic development.

5. Standard of Living: Increase in the standard of living of people in a community is yet another key goal of economic development. Entrepreneurs again play a key role in increasing the standard of living in a community. They do this not just by creating jobs, but also by developing and adopting innovations that lead to improvements in the quality of life of their employees, customers, and other stakeholders in the community. For example, automation that reduces production costs and enables faster production will make a business unit more productive, while also providing its customers with the same goods at lower prices.

6. Exports: Any growing business will eventually want to get started with exports to expand their business to foreign markets. This is an important ingredient of economic development since it provides access to bigger markets, and leads to currency inflows and access to the latest cuttingedge technologies and processes being used in more developed foreign markets. Another key benefit is that this expansion that leads to more stable business revenue during economic downturns in the local economy.

\section{Community Development: Economic} development doesn't always translate into community development. Community development requires infrastructure for education and training, healthcare, and other public services. For example, you need highly educated and skilled workers in a community to attract new businesses. If there are Table 1. Summary of variables. educational institutions, technical training schools and internship opportunities, that will help build the pool of educated and skilled workers.

A good example of how this kind of community development can be promoted is Azim Hashim Premji, Chairman of Wipro Limited, who donated Rs. 27,514 crores for promoting education through the Azim Premji Foundation. This foundation works with more than 350,000 schools in eight states across India.

So, there is a very important role for entrepreneurs to spark economic development by starting new businesses, creating jobs, and contributing to improvement in various key goals such as GDP, exports, standard of living, skills development and community development.

\section{Methods Overview of Collected Data and Variable}

The position of entrepreneurship in the context of economic growth is investigated using a crosssectional data set for the year 2005 containing data for 77 different countries. All continents except Australia and Antarctica are represented. The year 2005 was chosen as the most recent year with sufficient data on entrepreneurship available. Countries were included on the basis of availability of data on their level of entrepreneurship in the year 2005. The resulting set of countries nonetheless constitutes a representative sample because of the wide variety of countries included in this data set. A panel data set (including data from multiple years) was not available because there was very little time series data available for the variable measuring entrepreneurship. A complete list of the selected countries is provided in the appendix. All the data is drawn from the World Bank's online World Development Indicators database (World Bank Group). Six different economic factors are examined in the statistical analysis. These factors will be represented by seven different variables. Five different interaction variables are also used in the statistical analysis. The seven different variables are intended to measure the levels of labour, capital, education, research and development spending, economic growth, entrepreneurship, and probusiness government policies in a given country. All these are continuous random variables except for the variable measuring pro-market government policies, which is a discrete random variable. Descriptions of these variables and explanations of why they were chosen follow. Table 1 shows the name of each variable, the variable label used in the model equations, and which economic factor the variable is intended to measure. 
International Journal of Engineering Applied Sciences and Technology, 2020

Vol. 5, Issue 6, ISSN No. 2455-2143, Pages 116-121

Published Online October 2020 in IJEAST (http://www.ijeast.com)

\begin{tabular}{|l|l|l|}
\hline Variable Name & Variable Label & Factor Being Measured \\
\hline $\begin{array}{l}\text { gross national income per capita, } \\
\text { (purchasing power parity as } \\
\text { measured in current international } \\
\text { dollars) }\end{array}$ & GNI & Economic growth \\
\hline business entry rate & Bantry & Entrepreneurship \\
\hline $\begin{array}{l}\text { percentage of the population in the } \\
\text { labour force }\end{array}$ & Labour & Labour \\
\hline $\begin{array}{l}\text { Per capita gross capital formation } \\
\text { (constant 2000 U.S. dollars) }\end{array}$ & precipitance & Capital \\
\hline $\begin{array}{l}\text { research and development spending } \\
\text { (percent of GDP) }\end{array}$ & Respond & Knowledge \\
\hline $\begin{array}{l}\text { Sum of per student expenditures for } \\
\text { primary, secondary, and tertiary } \\
\text { education (percent of per capita GDP) }\end{array}$ & Summed & Knowledge \\
\hline \begin{tabular}{l} 
Ease of Doing Business Index rating \\
\hline
\end{tabular} & Beas & Pro-market government policies \\
\hline
\end{tabular}

The variable used to measure economic growth is per capita gross national income, measured in current international dollars using the purchasing power parity technique. GNI is a widely used measurement of economic growth because it is usually seen as a good overall summary of how welloff the residents of a given country are (Todaro and Smith, pp.45-46). The purchasing power parity technique is used to avoid any distortions caused by the official exchange rates of different countries (Todaro and Smith, p.46). Business entry rate (the World Bank's terminology for this variable) estimates the level of entrepreneurship in a country. This variable provides newly registered businesses as a percentage of the total registered businesses in a given country for a given year. This is in line with other studies examining entrepreneurship by using business start-up rates as an approximation for the level of entrepreneurship in a given area (Audre's and Keelback, p. 609). Dividing by the total number of registered businesses allows direct comparison between countries with economies of different sizes. Although this measure does not take non-profit entrepreneurs into account, it is held to be a good indicator of the level of entrepreneurship in a given country. The variables reflecting the amounts of labour and capital in a given country are the percentage of the population that is in the labour force and the per capita gross capital formation. Gross capital formation per capita is measured in constant 2000 U.S. dollars, again to reduce any distortionary effects of exchange rates. There are two main factors which influence the level of knowledge a country has: the size of the general body of knowledge and the level of education. A larger general body of knowledge will contain more economically useful pieces of knowledge, and a higher level of education in a country gives more people the ability to find the economically useful pieces of knowledge. Consequently, one variable is used to estimate the level of general knowledge in a country and another to estimate the number of people who are able to use that general knowledge. Both contribute to the level of knowledge in a country. Since the point of research is to create new knowledge, research is the most effective way to expand the general knowledge base. Thus, using research and development spending as a percentage of GDP is used to estimate the level of general knowledge in a country. This measurement includes both private and government research and development spending. A possible objection to using research and development spending as an estimate for how much general knowledge is available in a country might be that general knowledge is not limited by geographic distance. This would mean that once a piece of new knowledge has been generated by research it becomes available to people all over the world, not just to those people in the country that did the research. A country could thus have virtually no research and development spending but still have 


\section{International Journal of Engineering Applied Sciences and Technology, 2020 \\ Vol. 5, Issue 6, ISSN No. 2455-2143, Pages 116-121 \\ Published Online October 2020 in IJEAST (http://www.ijeast.com)}

access to a large general body of knowledge, assuming other countries did have high levels of research and development spending. However, a study by David Audre's and Erik Lehmann found that new businesses based on a new piece of knowledge tend to be clustered around the source of the new knowledge (Audre's and Lehmann, p. 1200). If the transmission of new knowledge were not limited by geographical distance then there would be little reason for these new firms to stay close to the original source of the knowledge. This indicates that geographic distance does, in fact, limit the spread of new knowledge. However, there are two other issues with using research and development spending as a measure of the general level of knowledge in a country which cannot be addressed as easily. The first of these is that official R\&D expenditures would not include any general knowledge available only in underground markets. Of course, the underground entrepreneurs who make use of such knowledge would most likely not be included in the official measure of business entry rate. Thus, while important to keep in mind, this should not unduly influence the results of the regressions described below. The other issue is that in some cases the knowledge generated by private R\&D expenditures may be held as proprietary information and thus not available to the general public. This implies that private $R \& D$ expenditures would have a weaker impact on the knowledge bases of countries than public R\&D spending. However, this effect is mitigated by the fact that the analysis presented here considers total R\&D expenditures (i.e. the sum of public and private $R \& D$ ). To estimate the level of education in a country, the sum of per student expenditures for primary, secondary, and tertiary education (as a percentage of per capita GDP) is used. A country's rating on the World Bank's Ease of Doing Business Index is used to reflect how pro-market the governmental policies in a given country are. This index ranges from 1 to 175 , with 1 indicating the governmental regulations most conducive to doing business. It is important to note that this variable only measures how conducive the government policies in a given country are to doing business, not how easy it is to actually do business in that country at any given time. For example, a country in the middle of a major economic depression might still receive a favorable Ease of Doing Business rating if that country's government does not excessively regulate the private sector during the depression. The interaction variables will consist of labour, precipitance, respond, summed, and base each being multiplied by Bantry. Their labels consist of the names of the two variables which are multiplied together, separated by an asterisk. The motivation behind checking for these interaction effects is to ascertain whether any of these variables would have a greater impact on a country's economic growth if a higher level of entrepreneurship were also present in that country. For instance, having a large labour force would contribute greatly to economic growth if a country had a high business entry rate, since there would be more jobs available and the country would thus have many productive workers. However, if the same country had a low business entry rate, a large labour force could be much less productive since many of its members would be unemployed.

\section{CONCLUSION}

The results from regression equation [1] confirm that entrepreneurship has a significant impact on economic growth as has been generally established. The regression for business entry rate (equation [2]) shows that the presence of entrepreneurship in a society cannot be completely explained by the traditional neoclassical factors that influence economic growth. Consequently, entrepreneurship should be included as an independent factor in the neoclassical model for economic growth. One of the themes in this paper has been that entrepreneurship causes economic growth by fostering innovation within a given society. Interestingly, the only factor significantly interacting with entrepreneurship was research and development spending, itself reflective of innovation (van Praag and Versloot, p. 354).

\section{REFERENCE}

1 Audre's, David and Keelback, Max.(2004)"Entrepreneurship and Regional Growth: An Evolutionary Interpretation." Journal of Evolutionary Economics Vol. 14,(p No.5, 605-616)

2 Audre's, David and Lehmann, Erik.( 2005) "Does the Knowledge Spill over Theory of Entrepreneurship Hold for Regions?" Research Policy, Vol. 34,(p No.8, , 1191-1202)

3 Bednarik, Robert W.( 2000) "The Role of Entrepreneurship in U.S. and European Job Growth." Monthly Labour Review, Vol. 123,(p No.7, 3-16)

4 Chemin, Matthieu. "The Impact of the Judiciary on Entrepreneurship:( 2008) Evaluation of Pakistan's 'Access to Justice Programme.", Journal of Public Economics, Vol. 93, ( pNo.1, 114-125)

5 Hubbard, R. Glenn.( 2008) "Non-destructive Creation: Entrepreneurship and Management Research in the Study of Growth." Journal of Policy Modelling, Vol.30, (No.4, , 595-602)

6 Kerzner, Israel.( 2008) "The Alert and Creative Entrepreneur: A Clarification.” Small Business Economics, Vol. 32,(p No. 2, , 145-152).

7 Otani, Kiyoshi. (1996) “A Human Capital Approach to Entrepreneurial Capacity." Economic, Vol. 63, (pNo. 250, , 273-289.) 
International Journal of Engineering Applied Sciences and Technology, 2020

Vol. 5, Issue 6, ISSN No. 2455-2143, Pages 116-121

Published Online October 2020 in IJEAST (http://www.ijeast.com)

8 Solow, Robert M(1956). "A Contribution to the Theory of Economic Growth." The Quarterly Journal of Economics, Vol.70(,pNo.1, , 65-94)

9 Pitlik, Hans(2002). "The Path of Liberalization and Economic Growth.” Kilos, Vol.29(p No.1 , 57-79)

10 Schumpeter, Joseph A(, 1934). The Theory of Economic Development: An Inquiry into Profits, Capital, Credit, Interest, and the Business Cycle. Cambridge: Harvard University Press

11 http://www.google.com/evoma.com, 